\title{
AMPICILLIN IN THE THERAPY OF CHRONIC BRONCHITIS
}

\author{
J. Robert MaY \\ Senior Lecturer in Bacteriology, Institute of Diseases of the Chest, London, S.W.3.
}

"Much was once hoped of ampicillin, but trials and clinical experience have shown it to have no advantage over tetracycline." Leading Article (1964), Brit. med. J., i, 719.

BEFORE attempting to compare the relative merits of any two drugs it is important to be clear as to what one is trying to achieve by their use. The main problems associated with the chemotherapy of chronic bronchitis are as follows.

Hamophilus influenza and the pneumococcus are widely accepted as being the most important pathogens in this and similar chest infections. The eradication of pneumococci seldom presents any difficulty, being usually achieved easily with relatively small doses of a variety of antibiotics; and rapid recurrence of pneumococcal infections is uncommon, since these organisms are usually killed, rather than inhibited, by the therapy. In contrast, Hamophilus influenzae has until recently been difficult to kill with currently available antibiotics; and it has been common experience that chronic infections caused by this organism tend to relapse soon after the end of apparently effective chemotherapy. It seems that the organism is merely inhibited by these antibiotics, and by some means at present unknown it can remain dormant until therapy is stopped, then re-emerging to continue its infective career.

The main problem, then, in planning chemotherapy of a patient with chronic bronchitisco

TABLE I

The Sensitivity of Hamophilus influenzae to Tetracycline, Penicillin G and Ampicillin

\begin{tabular}{lccccccc}
\hline Antibiotic & $\begin{array}{c}\text { Number of } \\
\text { strains tested }\end{array}$ & 5 & 2.5 & 1.25 & 0.6 & 0.3 & $\mu$ g./ml.. \\
& & & & & & & 0.15 \\
Tetracycline & 161 & $(161$ & 144 & 81 & 24 & 6 & 2 \\
& & 173 & $(90)$ & $(50)$ & $(15)$ & $(4)$ & $(1)$ \\
Penicillin G & 174 & $(100)$ & $(98)$ & 150 & 71 & 15 & 4 \\
& & 60 & 60 & 60 & $(41)$ & $(9)$ & $(2)$ \\
Ampicillin & 60 & $(100)$ & $(100)$ & $(100)$ & $(97)$ & $(52)$ & $(23)$ \\
& & & & & & &
\end{tabular}

TABLE II

The Sensitivity of Hamophilus influenza to Ampicillin

\begin{tabular}{lccccccc}
\hline $\begin{array}{l}\text { Action of } \\
\text { Ampicillin }\end{array}$ & $\begin{array}{l}\text { Number of } \\
\text { strains tested }\end{array}$ & 5 & 2.5 & 1.25 & 0.6 & 0.3 & \multicolumn{2}{c}{$\begin{array}{c}\mu \mathrm{g} . / \mathrm{ml} . \\
\end{array}$} \\
Bacteriostatic & 60 & 60 & 60 & 60 & 58 & 31 & 14 \\
& & $(100)$ & $(100)$ & $(100)$ & $(97)$ & $(52)$ & $(23)$ \\
Bactericidal & 19 & 19 & 18 & 17 & 10 & 5 & 0 \\
& & $(100)$ & $(95)$ & $(89)$ & $(53)$ & $(26)$ & \\
\hline
\end{tabular}

For 12 strains, the M.B.C.s and M.I.C.s were the same.

For 5, M.B.C.s were twice the M.I.C.s.

For one strain, M.B.C. was 4 times the M.I.C. and for one, 8 times. 
is the provision at the site of infection of a concentration of antibiotic sufficient to kill Hamophilus influenza.

Table I shows the bacteriostatic activity of tetracycline, penicillin $\mathrm{G}$ and ampicillin against a representative selection of strains of $H$. influenza. A concentration of $1.25 \mu \mathrm{g}$. of tetracycline per ml., which is of the same order as the level attainable in the sputum with ordinary dosage regimes inhibits $50 \%$ of strains; but, since at least ten times this concentration is required to kill the organisms, the prospect of achieving more than temporary suppression in vivo is remote.

The same proportion of strains $(50 \%)$ is inhibited by a concentration of about $1 \mu \mathrm{g}$. of penicillin $\mathrm{G}$ per $\mathrm{ml}$. The bactericidal concentration is only some two to four times higher, but the penetration of penicillin $G$ into the lung is such that the attainment of levels sufficient to kill (or sometimes only to inhibit) $H$. influenzae requires the injection of doses of the order of 8-10 mega units daily (May, 1955).

Inhibition of $50 \%$ of strains by ampicillin is achieved with a concentration of only 0.3 $\mu \mathrm{g} . / \mathrm{ml}$., and Table II indicates that only twice this concentration is enough for a bactericidal effect. On the basis of sensitivity tests in vitro, therefore, ampicillin should be superior to both penicillin $G$ and tetracycline in its ability to suppress $\boldsymbol{H}$. influenza, and it is possible that this antibiotic may be able to kill the organism in the bronchi, provided that penetration into the sputum is adequate.

The significance of antibiotic concentrations estimated in sputum must be assessed withz caution. First, it is not known how accuratelyo the sputum levels reflect the levels at the ${ }^{c}$ site of infection within the bronchial wall, $\overrightarrow{\overline{\mathrm{w}}}$ although experience has shown that predictions of the therapeutic value of penicillin $G$, $\frac{}{-}$ based on laboratory investigations, are more $\overline{\bar{s}}$ likely to be accurate if the sensitivity of the infecting organism is correlated with the con- $\frac{}{0}$ centration attainable in the sputum rather than ${ }^{\circ}$ the concentration attainable in the blood (May, $\vec{\circ}$ 1955). Secondly, the estimation of antibiotic concentration in sputum is subject to con- $\bar{\omega}$ siderable experimental error owing to dilutiono with saliva. As the extent of this is unknown, 3 allowance cannot be made for it. Thirdly, some form of diffusion method must be used for the estimation, since the presence of bacteria in sputum precludes titration. Diffusion methodso for the estimation of antibiotics can, of course, $\vec{c}$ give highly accurate results if the conditions of $\omega$ testing are properly controlled, but the facilities $\bigcirc$ available in most hospital laboratories seldomallow the ideal conditions to be realised. The results given in this paper were obtained by a cup-plate method using Sarcina lutea as the 3 test organism, the sputum being first homo-黑 genised with pancreatin (May, 1955).

Table III shows the concentrations of amw cillin found in the sputum six hours after doses of $250 \mathrm{mg}$. and $500 \mathrm{mg}$. The subjects investigated were patients with chronic bronchitis who were expectorating a sufficient quantity of sputum to be able to produce samples at $\bar{D}$ specified times. Each patient was receiving doses of ampicillin six-hourly, and sputum

TABLE III

Concentration of Ampicillin in Sputum 6 hours after a Dose.

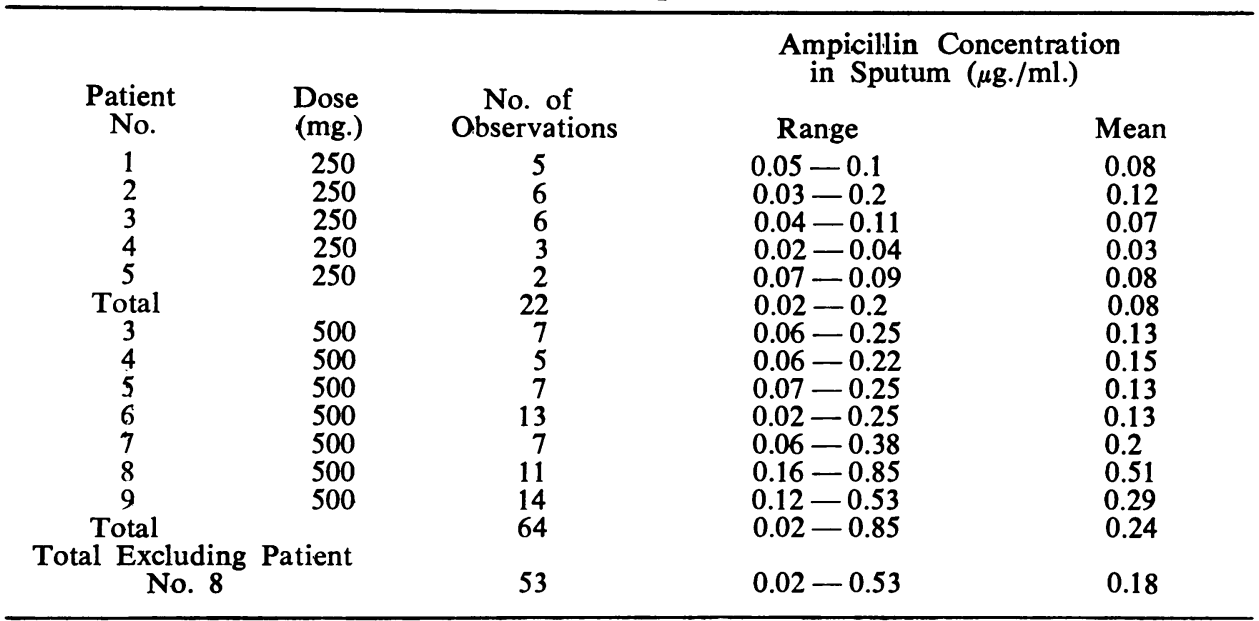


TABLE IV

Concentration of Ampicillin in Sputum during a Dosage Regime of 1 gram 6 hourly.

\begin{tabular}{|c|c|c|c|c|}
\hline $\begin{array}{l}\text { Patient } \\
\text { No. } \\
24 \\
25 \\
26 \\
27\end{array}$ & $\begin{array}{c}\text { Time of } \\
\text { Observation } \\
6 \text { hours } \\
\text { After } \\
\text { Dose }\end{array}$ & $\begin{array}{c}\text { No. of } \\
\text { Observations } \\
6 \\
8 \\
10 \\
3\end{array}$ & $\begin{array}{c}\text { Ampicillin Concentrations } \\
\text { Range } \\
0.08-1.08 \\
0.06-0.85 \\
0.13-0.6 \\
0.14-0.33\end{array}$ & $\begin{array}{l}(\mu \mathrm{g} . / \mathrm{ml} .) \\
\text { Mean } \\
0.44 \\
0.3 \\
0.32 \\
0.26\end{array}$ \\
\hline Total & & 27 & $0.06-1.08$ & 0.33 \\
\hline $\begin{array}{l}27 \\
28 \\
29 \\
30 \\
31\end{array}$ & $\begin{array}{l}24 \text { hour } \\
\text { Specimens }\end{array}$ & $\begin{array}{l}3 \\
3 \\
5 \\
5 \\
3\end{array}$ & $\begin{array}{l}0.12-0.39 \\
0.37-0.8 \\
0.3-0.49 \\
0.65 二-1.4 \\
0.02-0.1\end{array}$ & $\begin{array}{l}0.27 \\
0.6 \\
0.37 \\
0.94 \\
0.05\end{array}$ \\
\hline Total & & 19 & $0.02-0.8$ & 0.45 \\
\hline
\end{tabular}

samples were obtained just before the doses were taken. Several observations were made on most patients and the range of concentrations found was sometimes wide. With the exception of patient No. 8, however, there was a considerable degree of consistency of the mean concentrations for individual patients, the mean level for a dose of $250 \mathrm{mg}$. being $0.08 \mu \mathrm{g} . / \mathrm{ml}$. and that for $500 \mathrm{mg}$. (excluding patient No. 8) approximately twice as high. Patient No. 8, for no discernible reason, expectorated sputum from time to time containing an exceptionally high ampicillin level, but such a response was unusual.

In Table IV are shown the ampicillin concentrations detected in the sputum of 8 patients receiving a dose of 1 gram every six hours. Latterly, estimations were made on the pooled 24-hour output of sputum instead of single samples expectorated six hours after a dose. As far as can be judged from the findings in such a small series the results of both procedures are similar. It will be noted that in patient No. 27, in whom first one method and then the other were adopted, the two results were the same.

The results given in Tables I-IV are summarised in Table V. From this table one might predict that the best one can expect from 250 mg. six-hourly is suppression of one quarter of the infections, with subsequent relapse being the rule. $500 \mathrm{mg}$. six-hourly might be expected to suppress up to one half the infections, with reasonable prospect of complete eradication of the organism in many instances. 1 gram six-hourly should suppress the majority of infections, again with a good prospect of eradication in many instances. The dose marked "?", which ought to provide a bactericidal concentration in the sputum of almost all patients, will be discussed below.

How do the observed results correlate with the predictions? Table VI gives a summary of the more important features of the responses of a small number of patients treated with doses of $250 \mathrm{mg}$. or 1 gram every six hours for one week. Most of these patients are taking part in an investigation being conducted in association with Dr. Hurford and Dr. Little at King George V Hospital, Godalming, to whom I would like to express my thanks for allowing me to quote this material.

Hamophilus influenza was isolated from all patients before treatment. The need for therapy was indicated by macroscopic pus in the sputum; when this was present a week's

TABLE V

Ampicillin in Sputum

Summary of Sputum Levels and Sensitivity of $\boldsymbol{H}$. Influenza

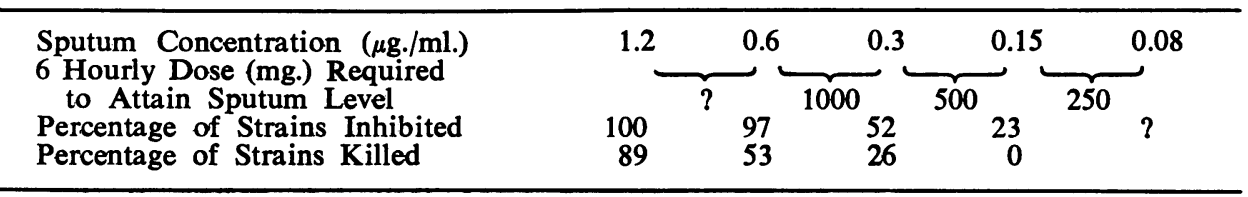


TABLE VI

Response of Patients With Purulent Chronic Bronchitis to 1 Week Courses of Ampicillin

\begin{tabular}{|c|c|c|c|c|c|c|}
\hline Dose & $\begin{array}{c}\text { No. of } \\
\text { Patients }\end{array}$ & $\begin{array}{l}\text { No. Failing } \\
\text { To Respond }\end{array}$ & $\begin{array}{c}\text { Average } \\
\text { Observation } \\
\text { Period }\end{array}$ & $\begin{array}{c}\text { Findings for } \\
\text { First } \\
\text { Recurrence }\end{array}$ & $\begin{array}{c}\text { Those Who } R \\
\text { No. of } \\
\text { Recurrences }\end{array}$ & $\begin{array}{l}\text { Responded } \\
\text { Equivalent } \\
\text { S Weekly Dose }\end{array}$ \\
\hline $\begin{array}{l}250 \mathrm{mg} .6 \mathrm{hrly} . \\
1 \mathrm{~g} .6 \mathrm{hrly} .\end{array}$ & $\begin{array}{r}8 \\
14\end{array}$ & $2^{1}$ & $\begin{array}{l}11.7 \text { weeks } \\
12 \text { weeks }\end{array}$ & $\begin{array}{c}7 \text { days } \\
59+\text { days }\end{array}$ & $\begin{array}{l}3.6 \\
1\end{array}$ & $\begin{array}{c}3 \text { grams. } \\
4.5 \text { grams. }\end{array}$ \\
\hline
\end{tabular}

course of the appropriate dosage regime was given, being repeated as necessary for recurrences. At the end of the period of observation the number of recurrences was noted and the total amount of ampicillin given during the period was expressed as an equivalent weekly dose.

The response to $250 \mathrm{mg}$. six-hourly was rather better than predicted. Only one patient out of eight failed to lose his pus during treatment, compared with a predicted $75 \%$ failure rate (Table V); this suggests that the tissue ampicillin concentrations are in fact higher than the sputum levels. The average time for recurrence of infection, however, was only seven days after the end of treatment, suggesting that the hæmophilus had only been temporarily suppressed; and most patients had 3-4 recurrences during the three month period. Such a response is in all respects similar to that expected from tetracycline given in the same dose.

The contrast with the patients receiving $1 \mathrm{~g}$. six-hourly is striking, even with this small number of patients. The long period of freedom from infection after treatment suggests that the Hamophilus influenza had been killed $\overrightarrow{0}$ by the ampicillin, and recurrence, when it eventually occurred, was presumably the result $\vec{\rho}$ of exogenous reinfection rather than endogenous relapse. It is interesting that the aver- $\frac{0}{3}$ age equivalent weekly dose for the 1 gram six-hourly regime is only $50 \%$ higher than that. for $250 \mathrm{mg}$. six-hourly. This represents an? eight-fold improvement in the efficiency of utilization of ampicillin.

The two complete failures amongst those ${ }^{\omega}$ receiving 1 gram six-hourly indicate that this 5 regime, as was predicted, is still inadequate; to eradicate all hæmophilus infections; and this $\mathbb{\Phi}$ raises the question of the nature of the ? in $\Phi$ Table V-the dosage that will eradicate most infections. Possibilities are:-a larger dose thath 1 gram by mouth, 1 gram + probenecid ${ }_{0} \vec{c}$ potentiate the levels, or perhaps a short course of high dosage intramuscularly. These pos:sibilities are now being investigated, but, what-o ever the final conclusion, it seems possible that eventually ampicillin may after all be shown to have considerable advantages over tetracycline. $\frac{\mathrm{D}}{\mathrm{Q}}$

\section{REFERENCE}

MAY, J. R. (1955): Brit. J. Tuberc., 49, 166.

\section{DISCUSSION}

Tunevall (Stockholm): Dr. May's therapeutic study starts out from our general belief that $H$. influenza and pneumococci are the most important pathogenic agents in chronic bronchitis. This is an old conviction put forward by S. D. Henriksen in Norway in a very painstaking investigation in 1937, before the introduction of penicillin. Until recently, however, this opinion was mainly founded on results of sputum cultures. The common occurrence of an organism in expectorates cannot per se be taken as proving the ætiological significance of the same organism.
The sputum findings do not adequately reflect the bacterial flora of the lower air pass- $\frac{3}{?}$ ages as can be seen in the Fig. 1. In this are presented the cultural findings from pharyngeal swabs, sputum and bronchial secretions 0 (obtained at bronchoscopy), from a little more ${ }^{N}$ than a hundred patients with chronic bronchial N disease but without exacerbation at the time of sampling. The lack of coincidence is obvious.o The only organisms dominating in bronchial secretions are $H$. influenzae and, less frequently,? pneumococci. 